\title{
ASPECTS CONCERNING EXTERNAL PARTNERSHIPS OF ROMANIA AFTER THE SECOND WORLD WAR
}

\author{
Florina Popa \\ Academia Română, Institutul de Economie Naţională \\ florinapopa289@gmail.com
}

\begin{abstract}
After the ending of the Second World War, Romania's cooperation relations with other countries were subordinated to the political and economic situations developed among the world states and to the events that followed the completion of the war, the form and content of these relations being different, corresponding to the context. The study presents aspects related to the partnership relations developed through the economic cooperation relations achieved by Romania within the Commission for Reciprocal Economic Aid-COMECON (CAER), on the period of its operation (1949-1989). There are presented participants' cooperation modalities, the partnership being of public-public or public-private type. The examples shown include elements regarding the participating parties, the objectives to be achieved, the period, participation share, as the case may be. Also, some references are made to the enlargement of Romania's economic cooperation relations, internationally, after the 1970 year, expression of the favorable evolution of the geographical space of manifestation of the Romanian foreign trade.
\end{abstract}

\section{Keywords}

Cooperation; foreign trade; partnership; mixed companies; COMECON (CAER); international cooperation; socialist countries

\section{JEL Classification}

F13; F15; H44; L24; L32; M16; O19; P33; P35

\section{Economic cooperation within the Council for Mutual Economic Assistance - COMECON (CAER) (1954 - 1989)}

The changes known by the Romanian economy and its orientation towards the pronounced development of the industry, especially, the heavy industry, were reflected in the structure of the foreign trade and its evolution (Muresan \& Muresan, 1998).

After the year 1949, the foreign trade, over which the state held the total monopoly, was oriented towards relations, in the form of trade exchanges with U.S.S.R. (the Union of Soviet Socialist Republics) (U.R.S.S.) and the neighboring states.

U.S.S.R. promoted cooperation at regional level, through trade exchange, initiating, in 1949, the formation of the Council for Mutual Economic Assistance - COMECON (CAER) - an organization to which, European countries, initially, joined. Founding members were Bulgarian People`s Republic, Czechoslovak Socialist Republic, Polish People`s Republic, Socialist Republic of Romania, Hungarian People`s Republic and U.S.S.R.. Subsequently, the German Democratic Republic (1950), the Mongolian People's Republic (1952), the Republic of Cuba (1972), the Socialist Republic of Vietnam (1978) joined. Also, on the basis of conventions, cooperation relations were concluded with Socialist Federal Republic of Yugoslavia, Finland, Mexico, Iraq, and so on. Other international institutions and agencies had cooperation relations with COMECON (CAER), too, namely: the Investment Bank for Economic Cooperation, 
the International Investment Bank, as well as branch international economic unions of (Intermetal - 1965, Interchim - 1970, Interelectro - 1973, Interatomenergo - 1973) (Costache, 2012).

Within the organization, the status could be as a full member, associate member, in cooperative relations. The coordination of Romania's economic and technical-scientific activity within COMECON (CAER) was done by a Governmental Commission.

The particularities of leading and coordination of the country's economy were reflected in the relations developed with the COMECON (CAER) member states, under the conditions of the legislative framework created by the Romanian state, in the organization of the economic sector. According to the Constitution, the state had the role of planning and coordination of the country's economy (Costache, 2012).

Collaboration within this organization evolved into several goals (Costache, 2012):

- Coordination of national economic plans;

- Coordination of investment plans;

- Establishment of enterprises, joint property of several countries;

- Specialization of industrial production;

- Establishment of international economic unions.

\subsection{Types of co-operation within Council for Mutual Economic Assistance - COMECON (CAER)}

As regards the types of co-operation, according to the specialists, it is concretized as follows:

One of the forms, most often met, is the mixed type economic units which could have, in a narrow meaning, the significance of mixed production societies - "units at which partners from countries with different socio-economic systems participate in", or broader, "economic units at which enterprises, firms from different countries, regardless of their social structure, participate in" (Albu, 1985). Participation may take place among public-public or public-private type units, as appropriate.

Their goal was the achievement of some economic objectives, to satisfy some common interests for all partners, in advantageous conditions,

The mixed economic units may develop East-East, East-West type partnership relationships and are of bilateral or multilateral character. It holds attention, a number of partnership actions to which Romania participated alongside other COMECON (CAER) member states, through various types of collaboration :

a) Bilateral cooperation among the socialist countries in the form of mixed-bilateral type units

$>$ The agreement between Socialist Republic of Romania (Republica Socialistă România) and Bulgarian People`Republic (Republica Populară Bulgaria) concerning the establishment of the Giurgiu-Rousse common enterprise, approved on 28 June 1977, through HCM no.144, in the sphere of the construction of heavy machinery and equipment (Albu, in Albu Alexandru D. et al., 1985, p. 66).

The objective was the achievement of a microeconomic specialization, the two countries collaborating in the elaboration of projects and construction documentations assembly and operation of production capacities.

- The Giurgiu Unit produced small and medium depth drilling equipment, chemical and petrochemical equipment, industrial fittings, utility vehicles, cast iron and non-ferrous dead-mould castings (Albu, in Albu Alexandru D. et al. 1985, p. 66).

- The Ruse Unit produced technological equipment for mining drilling and for ore processing, metallurgical, chemical and petrochemical equipment, 
steel dead-mould castings and forged pieces. (Albu, in Albu Alexandru D. et al., 1985, p. 66).

Porţile de Fier (I şi II) Hidropower and Navigation System, a common Romanian-Yugoslav enterprise of cooperation, aiming at capitalize the Danube resources in the Porţile de Fier area. The cooperation focused on two objectives (Albu Alexandru D., in Albu Alexandru D. et al., 1985, p. 67):

- Objective 1 - the construction of a power plant of 1050-MW power, for each part - it was achieved through an agreement signed on 30 November 1963.

- Objective 2 - the construction of two hydroelectric power plants, whereby, each part to be provided with electricity, at the amount of $1200 \mathrm{MW} /$ year; the construction of two spillways and two flood gates for navigation - by Agreement signed on 19 February 1977.

The two parts cooperated to bring together the common capacities of diking and water yaw, technical complementary documentations to jointly develop studies, projects, etc., but also, jointly undertaking of measures designed to increase the energetic capacity of the project (Albu Alexandru D. in Albu Alexandru D. et. al., 1985, p. 67).

$>$ Stînca-Costeşti Hydroenergetic Node on the Prut River, S.R.R. - U.S.S.R. (R.S.R. - U.R.S.S.) joint enterprise, established by the Governmental Agreement signed on 16 December 1971. The common goal was the creation of a barrier lake with a volume of 1400 million c.m., which to ensure the following objectives (Albu Alexandru D., in Albu Alexandru D. et al., 1985, p. 67):

- Prevention and control of floods, along the Prut River, on both territories, on an area of 100000 ha;

- Ensuring some water debits towards irrigate an area of 70000 ha, for each territory;

- Construction of two hydroelectric power stations of $15 \mathrm{MW}$, for each part, in order to achieve some constant debits of drinkable and industrial water, for each of the parts, of 5-8 c. m.

From the total value of the works, of 61867 transferable rubles: the Romanian part contributed with 30942 thousand rubles and the Soviet part, 30925 thousand rubles. (Albu Alexandru D., in Albu Alexandru D. et al., 1985, p. 67).

The form of cooperation through the establishment of joint enterprises has had positive results, by:

- ensuring opportunities to harness the resources of both states, without affecting the sovereignty of the participant States;

- joint investment efforts for large projects, developed on several plans;

- the development of products which involve complex technologies.

By mixed units made in partnership with socialist countries (enterprises), a wide exchange of managerial experience and professional training of specialists has been achieved.

\section{b) Cooperation through mixed- multilateral type units}

There were two types of mixed-multilateral type units, classified under the Comprehensive Program of deepening and forward improvement of the collaboration and development of the economic socialist integration of the COMECON (CAER) member countries (Programul complex al adâncirii şi perfecţionării în continuare a colaborării şi dezvoltării integrării economice socialiste a ţărilor membre CAER)

$\Rightarrow$ Organizations that had the function of cooperation coordination, in different fields, such as: Interchim - in the small tonnage chemical industry; Intermetal - 
in steel production; Interelectro - in the field of electrotechnical industry; FCC joint use of containers in international traffic (Albu Alexandru D., in Albu Alexandru D. et. al., 1985, p. 53, Costache B., 2012).

$\Rightarrow$ Organizations or economic unions which, beside the coordination function, also, unfolded their own revenue-producing activity, in which enterprises, organizations, research institutes, from different member countries has participated (Albu Alexandru D. in Albu Alexandru D. et. al., 1985, p. 54). In the period 1973-1975, multilateral partner organizations of this type were created, reflecting the cooperation in different fields, as exemplified (Albu Alexandru D., in Albu Alexandru D. et al., 1985, p. 54):

- Interchimfibre with a 10-year life span (1974-1984), created on 21 June 1974, by convention signed by the governments of the countries: B.P.R. (R.P.B.), C.S.R. (R.S.C.), G.D.R. (R.D.G.), P.P.R. (R.P.P.), S.R.R. (R.S.R.), H.P.R. (R.P.U.) and U.S.S.R. (U.R.S.S.), with headquarters in Bucharest; the objective was to meet the chemical fibres requirements of the participant countries, to the qualitative standards of the best assortments in the world (Albu Alexandru D., in Albu Alexandru D. et al., 1985, p.58, Costache B., 2012, p. 107);

- Intertextilimaş with the headquarters in Moscow - whose activity targeted the production of machinery and technological equipment, needed for the textile industry (Albu Alexandru D., in Albu Alexandru D. et al., 1985, p. 54, Costache B., 2012, p. 107);

- Interatomenergo with the headquarters in Moscow - whose activity focused on the mutual production and delivery of equipment and the provision of technical assistance in the construction of nuclear power plants (Albu Alexandru D., in Albu Alexandru D. et al., 1985, p. 54, Costache B., 2012, p. 104).

- "Cooperation with companies from Hungary, in the production of wagons, machine-tools, Diesel engines, equipment, for the food industry;

- Cooperation with companies from German Democratic Republic, in optical industry, manufacture of machine-tools, electrical transformers;

- Cooperation with Yugoslavia in the production of Diesel motors and electric motors, auto-trucks, electric household appliances, fabrication of passenger airplanes, with Britten Norma company in England, etc. ."

The cooperation of the socialist member countries, within COMECON (CAER), through this type of international organizations/unions - mixed units made in partnership with socialist countries (enterprises), was advantageous because:

- they organized economic and technical - scientific development directions and plans;

- sustained the economic growth in the relative countries, over the long term;

- determined specialization in production;

- ensured coverage of some scarce production at COMECON (CAER) level;

- a large series production was achieved, by mobilizing common financial, technological and human resources;

- development of research, projection, production and commercialization activities;

- exchange of experience, possibilities of penetration of technical progress, in different fields.

c) Jointly participation in the creation of capacities for the capitalization of raw materials 
Mutually beneficial conventions between the U.S.S.R. (U.R.S.S.) and other socialist countries, concerning co-operation for jointly creation of some production capacities in the raw materials field (Albu Alexandru D., in Albu Alexandru D. et al., 1985, p. $61)$.

$\Rightarrow$ Multilateral Convention for the Production of Cellulose at Ust Ilim, signed in June 1973 among B.P.R. (R.P.B.), G.D.R. (R.D.G.), P.P.R. (R.P.P.), S.R.R. (R.S.R.), H.P.R. (R.P.U.) and U.S.S.R. (U.R.S.S.), for creating a capacity of 600 thousand tons, annually, of stationer cellulose, capacity that came into operation in 1978. Romania participated, by investments, in the guise of credit deliveries (with an interest of $2 \%$ per year), machinery, equipments, consumer goods (furniture, clothing and knitwear) and various materials. The reimbursement consisted of the delivery to Romania, of 50 thousand tons of cellulose per year, over 20 years, since objective coming into operation (Albu Alexandru D., in Albu Alexandru D. et. al., 1985, p. 61).

$\Rightarrow$ Convention of co-operation for the Extraction and Processing of Asbestos, in Kiembai, signed in September 1973, among B.P.R. (R.P.B.), C.S.R. (R.S.C.), G.D.R. (R.D.G.), P.P.R. (R.P.P.), S.R.R. (R.S.R.), H.P.R. (R.P.U). and U.S.S.R. (U.R.S.S.) Participation of S.R.R. (R.S.R.) was carried out by deliveries of credits (with interest of $2 \%$, annually), which was reimbursed after the commune's carring into action - 45 thousand tons of asbestos, annually, over 20 years (Albu Alexandru D., in Albu Alexandru D et al., 1985, p. 61).

$\Rightarrow$ Convention of Co-operation for the construction of the gas pipeline, with an ammount of 30 billion c.m, annually, to capitalize the Crenburg deposit, signed by B.P.R. (R.P.B.), C.S.R. (R.S.C.), G.D.R. (R.D.G.), P.P.R. (R.P.P.), S.R.R. (R.S.R.), H.P.R. (R.P.U.) and U.S.S.R. (U.R.S.S.) in February 1976. Romania contributed with 127 billion rubles, of which 95 billion rubles, in freely convertible currency, needed for procurement of some special equipments in West. The contribution of the other socialist countries was, in particular, with equipments and labour (Albu Alexandru D., in Albu Alexandru D. et al., 1985, p. $61,62)$.

As a result of these co-operations, the participant socialist countries were provided with raw materials, for a period of 20 years. (Albu Alexandru D. et al., 1985).

\section{International economic cooperation}

This form can be considered an element of improving and balancing the world economy, by the simultaneously exchange of material values that it engages, thus, mitigating the effects of the economic crisis. (Albu Alexandru D. et al., 1985)

After the year 1970, Romania made efforts towards broadening the economic relations with as many countries as possible, the geographical space of the manifestation of the Romanian foreign trade, evolving favorably, from one stage to another, corresponding to the development of the economy.

If at the beginning of the '50 years, the main partner, as share in the country's trade relations, was the U.S.S.R. (U.R.S.S.) (60.8\% of exports and $43 \%$ of imports) and less other countries in the Central and Eastern Europe, in the '60 years, the relations with COMECON (CAER) Member States reached $73 \%$ and with developed or developing countries, 27\%; after the year 1970, this report changed, the share of trade relations with non-socialist countries increasing to $55.2 \%$.

In the year 1989, Romania had, globally, trade relations with 59 countries, developing international economic cooperation relations: mixed production companies, mixed 
companies with headquarters in Romania, mixed production companies with headquarters abroad, cooperation through sub-production or subcontracting, delivery of equipment and machines on credit repayable in products (the Romanian formula of industrial cooperation), international cooperation in the banking and credit field, bilateral co-operation in the field of tourism.

Romania had relations of cooperation and economic exchanges with European countries (Great Britain, Italy, France, German Federal Republic, U.S.S.R. (U.R.S.S.), German Democratic Republic, Czechoslovak Socialist Republic, Polish People's Republic, Hungarian People`s Republic; Asian countries (Saudi Arabia, China, Iran, Japan, Kuwait, Syria Turkey); in the American continent (U.S.A., Canada, Cuba, Brazil); some African countries (Egypt, Morocco, Tunisia). (Mureşan M. \& Mureşan D. 1998, p. 373).

The international cooperation relations were found in several areas of activity: production, science and technics, marketing and commercialization, banking and lending activities, services area.

The cooperations developed by Romania, internationally, in various forms and in various fields, with different states, are shown in the table below (Table 1):

Table 1 Actions of international economic cooperation developed in Romania

\begin{tabular}{|c|c|c|c|c|c|c|}
\hline & 1975 & 1976 & 1977 & \multicolumn{3}{|c|}{ from which: } \\
\hline & & & & $\begin{array}{l}\text { Socialist } \\
\text { countries }\end{array}$ & $\begin{array}{l}\text { Developing } \\
\text { countries }\end{array}$ & $\begin{array}{l}\text { Developed } \\
\text { capitalist } \\
\text { countries }\end{array}$ \\
\hline $\begin{array}{l}\text { Mixed production } \\
\text { companies in R.S. } \\
\text { România }\end{array}$ & 6 & 8 & 9 & - & 1 & 8 \\
\hline $\begin{array}{l}\text { Mixed production } \\
\text { companies abroad }\end{array}$ & 24 & 27 & 28 & - & 27 & 1 \\
\hline $\begin{array}{l}\text { Commercial and } \\
\text { banking type } \\
\text { companies abroad }\end{array}$ & 31 & 35 & 35 & - & 6 & 29 \\
\hline $\begin{array}{l}\text { Cooperation and } \\
\text { specialization in } \\
\text { production, with } \\
\text { socialist countries }\end{array}$ & 27 & 44 & 57 & 57 & - & - \\
\hline $\begin{array}{l}\text { Achievements of } \\
\text { economic } \\
\text { objectives in } \\
\text { Socialist Republic } \\
\text { of România } \\
\text { (Republica }\end{array}$ & 22 & 11 & 31 & - & - & 31 \\
\hline
\end{tabular}




\begin{tabular}{|l|l|l|l|l|l|l|}
\hline $\begin{array}{l}\text { Socialistă } \\
\text { România) }\end{array}$ & & & & & & \\
\hline $\begin{array}{l}\text { Achievements of } \\
\text { economic } \\
\text { objectives abroad }\end{array}$ & 127 & 127 & 128 & 32 & 86 & 10 \\
\hline $\begin{array}{l}\text { Cooperations for } \\
\text { procurement of } \\
\text { raw materials in } \\
\text { socialist countries }\end{array}$ & 8 & 7 & 25 & 25 & - & - \\
\hline Total & 245 & 259 & 313 & 114 & 120 & 79 \\
\hline
\end{tabular}

Sursa: Constantin Moisuc (1978), "Participarea României la colaborarea economică internaţională", Editura Politică, Bucureşti, p. 130, quotes "Revista economică” nr. 33/1977; Revista "Lumea" nr. 34/1977

\section{Conclusions}

By participating in cooperation agreements within COMECON (CAER), Romania developed the country's economy, by industrialization, with an emphasis on the heavy industry, achieved the change of structure, by the stronger development of some branches and less, of others, pursued catching-up in the economic development.

There were shortcomings caused by the increase in energy consumption, lack of raw materials and minerals, corresponding to the needs of some industries, as well as the development of some industries whose products were not competitive on the external markets of COMECON (CAER).

In the relations with this organization, the governors of the country taked into account, as a priority, the assertion and conservation of the economic independence of Romania. Within COMECON (CAER), Romania did not get involved in actions, at industrial level, which meant economic integration. At the same time, it targeted towards the cooperation with Western capitalist countries, whom share had grown much, up to the end of the eighth decade.

The process of international cooperation and its expansion with capitalist countries has brought to Romanian economy, a number of advantages (Popa I. in Albu Alexandru D. et. al., 1985, p. 362-363, Moisuc C., 1978):

- advantageous costs, due to the geographic proximity;

- improvement of relations of external trading;

- strengthening trade relations among partners;

- widening Romania's relations with the Western countries, lessening of some tariff and non-tariff barriers, close relations among partners;

- enhancing participation in the world economic circuit;

- promotion of Romanian exports;

- higher capitalization of resources;

- attracting financial sources and material resources from abroad;

- the penetration of technical progress through world modern technologies;

- training of specialists.

In the assessment of the efficiency of economic relations, at external level, it is worth mentioning that, although the products that were subject to export, were remarkable through the high quantitative volume, there were situations when they did not meet the qualitative requirements, consequence of the development of an industry, large raw materials and energy - consuming, with outdated technologies (Mureşan M. \& Mureşan D., 1998, p. 373). 


\section{References}

Albu, Alexandru, D. (coordonator), Hamzescu, Roşu, I.; Popa, I.; Ijdelea, R.; Olteanu, M.; Blidea, V. (1985), Cooperarea Economică Internaţională a R.S. România, Academia de Studii Economice, Facultatea de Comerţ, Catedra de Relaţii Economice Internationale, Bucureşti;

Albu, Alexandru, D. Ijdelea, R.; Blidea, V. (1985), Capitolul II Cooperarea internatională în producţie, (pag. 37-135) în Albu, Alexandru, D. (coordonator) et. al. (1985) Cooperarea Economică Internaţională a R.S. România, Academia de Studii Economice, Facultatea de Comerţ, Bucureşti, Catedra de Relaţii Economice Internationale, Bucureşti;

Albu, Alexandru, D. (1985), Capitlul VI Cooperare internatională în sfera serviciilor (pag.228-246) în Albu, Alexandru, D. (coordonator) et. al. (1985) Cooperarea Economică Internaţională a R.S. România, Academia de Studii Economice, Facultatea de Comerţ, Bucureşti, Catedra de Relaţii Economice Internationale, Bucureşti;

Albu, Alexandru, Blidea, V.; D.; Olteanu, M. (1985); Capitolul V Cooperarea internaţională în domeniul bancar şi al creditului (pag.204-227) în Albu, Alexandru, D. (coordonator) et. al. (1985) Cooperarea Economică Internaţională a R.S. România, Academia de Studii Economice, Facultatea de Comerţ, Bucureşti, Catedra de Relaţii Economice Internationale, Bucureşti;

Constantinescu, N. N. (coordonator) et. al. (2000), Istoria Economică a României, vol. II 1939 -1989, , Editura Economică, Bucureşti;

Costache B. (2012), Activitatea României în Consiliul de Ajutor Economic Reciproc 1949 - 1974, Academia Română, Institutul Naţional pentru Studiul Totalitarismului, Bucureşti;

Moisuc, C. (1978), Participarea României la colaborarea economică internaţională, Editura Politică, Bucureşti;

Mureşan, M.; Mureşan D. (1998), Istoria economiei, Editura Economică, Bucureşti;

Popa I. (1985), Capitolul VII Contractul de cooperare economică internatională (pag. 247-272), în Albu, Alexandru, D. (coordonator) et. al. (1985) Cooperarea Economică Internaţională a R.S. România, Academia de Studii Economice, Facultatea de Comerţ, Bucureşti, Catedra de Relaţii Economice Internationale, Bucureşti;

Popa I., Olteanu M., Ijdelea R., Capitolul X Evoluţii structurale şi direcţii geografice în cooperarea economică internaţională a R.S. România (pag. 344-367), în Albu Alexandru D. (coordonator) et. al. (1985) Cooperarea Economică Internaţională a R.S. România, Academia de Studii Economice, Facultatea de Comerţ, Bucureşti, Catedra de Relaţii Economice Internationale, Bucureşti;

Purcărea Th. (2000), Capitolul 8 Comerţul interior în perioada 1948 - 1989, (pag. 253 - 282), în N. N. Constantinescu (coordonator) et. al. (2000) Istoria Economică a României, vol. II 1939 -1989, Editura Economică, Bucureşti;

Sută N. (2000), Capitolul 9 Comerţul exterior al României în perioada 1949 - 1989, (pag. 283 - 310), în N. N. Constantinescu (coordonator) et. al. (2000) Istoria Economică a României, vol. II 1939 -1989, Editura Economică, Bucureşti;

Ţăranu Liviu (2007), România în Consiliul de Ajutor Economic Reciproc (1949 1965), Editura Enciclopedică, Bucureşti (Cuvânt înainte de Ion Agrigoroaiei);

Revista economică nr. 33/1977;

Revista "Lumea" nr. 34/1977;

Constituţia Republicii Populare Române din 1948, în Monitorul Oficial, nr. 87 bis din 13 aprilie 1948;

Convenţie din 13 decembrie 1973 privind înfiinţarea Uniunii economice internaţionale pentru organizarea cooperării în producţie a livrărilor de utilaje şi acordarea de 
asistenţă tehnică în construirea de centrale nuclearoelectrice „INTERATOMENERGO”, în Buletinul Oficial al R.S.R. nr. 63 din 18 aprilie 1974;

Convenţie din 13 decembrie 1973 privind înfiinţarea Uniunii economice internaţionale pentru producerea utilajelor tehnologice pentru industria textilă „Intertextilmaş”, în Buletinul Oficial al R.S.R. nr. 88 din 25 iunie 1974;

Convenţie din 13 decembrie 1973 privind crearea Organizaţiei internaţionale pentru colaborare economică şi tehnico-ştiinţifică în domeniul industriei electrotehnice „INTERELECTRO”, în Buletinul Oficial al R.S.R. nr. din 65 din 20 aprilie 1974;

Convenţie pentru înfiinţarea Uniunii economice internaţionale în domeniul fibrelor chimice „Interchimfibre”, în Buletinul Oficial al R.S.R. nr. 124, din 17 octombrie 1974;

Decret nr. 508 din 16 decembrie 1970 pentru aderarea Republicii Socialiste România la Convenţia privind instituirea Organizaţiei internaţionale de ramură de colaborare în domeniul producţiei chimice de mic tonaj „Interchimfibre”, în Buletinul Oficial al R.S.R, nr. 145 din 16 decembrie 1970;

Programul complex al adâncirii şi perfecţionării în continuare a colaborării şi dezvoltării integrării economice socialiste a ţărilor membre CAER.

\section{Acknowledgment}

The study is a part of the research paper of the Institute of National Economy, Romanian Academy (Institutul de Economie Națională, Academia Română) - "Rolul statului si parteneriatul public-privat (1918-2018)"- achieved in 2018, by a team of researchers - PhD. Cornel Ionescu (coordinator), PhD. Florina Popa. 